\title{
PEMILIHAN MODEL REVALUASI ASET TETAP DAN DAMPAKNYA TERHADAP NILAI PERUSAHAAN PADA SEKTOR PERBANKAN
}

\section{THE CHOOSING OF FIXED ASSET REVALUATION MODELS AND ITS EFFECTS ON COMPANY VALUE IN BANKING SECTOR}

\author{
${ }^{1}$ Muhammad Hidayat, ${ }^{2}$ Ravika Permata Hati \\ ${ }^{1,2}$ Program Studi Akuntansi, Fakultas Ekonomi \\ Universitas Riau Kepulauan, Indonesia \\ ${ }^{1}$ mhidayatb@fekon.unrika.ac.id \\ ${ }^{2}$ ravika.permata@fekon.unrika.ac.id
}

\begin{abstract}
Abstrak
Penelitian ini bertujuan untuk menguji apakah $L D R, C A R$, Size, dan Kepemilikan Asing berpengaruh signifikan terhadap pemilihan model revaluasi asset tetap.Penelitian ini menggunakan metode kuantitatif, analisis regresi logistik digunakan karena pemilihan model revaluasi aset tetap sebagai variabel independen merupakan variabel dikotomi.Untuk menguji apakah terdapat perbedaan signifikan antara pemilihan model revaluasi (fair value) dan pemilihan model biaya (historical cost) terhadap nilai perusahaan dilakukan dengan uji Mann-Whitney.Penelitian ini dilakukan pada perusahaan sektor perbankan yang terdaftar di Bursa Efek Indonesia pada tahun 20152016,dengan menggunakan purposive samplingditemukan sampel sebanyak 28 Bank. Hasil Penelitian menunjukkan bahwa Size, berpengaruh positif dan signifikan terhadap pemilihan model revaluasi asset tetap.Sedangkan $L D R, C A R$, dan Kepemilikan Asing tidak berpengaruh signifikan terhadap pemilihan model revaluasi asset tetap.Tidak terdapat pengaruh signifikan antara pemilihan model revaluasi asset tetapterhadap nilai perusahaan.
\end{abstract}

Kata Kunci: Model Revaluasi, Aktiva Tetap, Nilai Perusahaan, Likuiditas, CAR, Ukuran Perusahaan, Kepemilikan Asing.

\section{Abstract}

This study aims to test whether LDR, CAR, Size, and Foreign Ownership significantly influence in choosing of fixed asset revaluation model. This study uses quantitative methods, logistic regression analysis is used because the selection of fixed assets revaluation model as an independent variable is a dichotomy variable. To test whether there is a significant difference between the selection of the revaluation model (fair value) and the selection of the historical cost model of firm value is done by Mann-Whitney test. This research was conducted at the banking sector companies listed in Indonesia Stock Exchange in 2015-2016, using purposive sampling found a sample of 28 Bank. The result of the research shows that Size has positive and significant effect in choosing of fixed asset revaluation model. While LDR, CAR, and Foreign Ownership have no significant effect in choosing of fixed asset revaluation model. There is no significant influence between the selection of fixed asset revaluation model to firm value.

Keywords: Revaluation Model, Fixed Assets, Corporate Value, LDR, CAR, Company Size, Foreign Ownership 


\section{PENDAHULUAN}

Dikeluarkannya paket kebijakan ekonomi jilid V pada tahun 2015 yang memberikan insentif kepada pelaksanaan revaluasi asset, menyebabkan isu revaluasi asset ini kembali menghangat dibahas dibergai media di tanah air. Banyak perusahaan termasuk sektor perbankan yang merespon kesempatan ini untuk melakukan revaluasi asset tetapnya.Sejak diberlakukannya PSAK 16 (Revisi 2007) tentang asset tetap (sudah mengalami penyesuaian pada tahun 2011, 2014 dan 2015) dimana standar ini memberikan pilihan apakah menggunakan model biaya atau menggunakan model revaluasi untuk pengukuran asset tetapnya setelah pengakuan awal.Baridwan (2004:334) dalam Andison (2015) mengatakan bahwa apabila harga-harga sudah berubah dalam jumlah yang cukup besar maka akun aktiva tetap yang memakai harga perolehan dimasa lalu sudah tidak menunjukkan keadaaan yang riil dari aktiva tersebut. Kalau dilihat kondisi perekonomian di Indonesia pada beberapa tahun terakhir dimana tingkat inflasi masih berfluktuasi dan dengan kecenderungan inflasi masih tergolong tinggi yang menyebabkan nilai uang terus menurun dibandingkan nilai barang, sehingga hal ini akan berpengaruh terhadap nilai wajar aktiva yang dimiliki perusahaan.

Menurut Yulistia dkk.(2015) alasan bagi perusahaan untuk melakukan revaluasi asset adalah untuk memastikan bahwa nilai wajar dari aset tetap tercermin dalam laporan keuangan. Banyak pihak berpendapat bahwa penyajian asset tetap dalam nilai wajar akan lebih relevan dalam pengambilan keputusan ekonomi sehingga sudah seharusnya digunakan dalam pelaporan asset tetap (Wang, 2006). Menurut Missonier- Pieraal F. (2007) Revaluasi asset dapat meningkatkan citra laporan keuangan bagi para pemangku kepentingan dan dapat meningkatkan kapasitas pinjaman. Kebijakan revaluasi juga memberikan sinyal bahwa investor memiliki peluang untuk memperoleh keuntungan atas investasinya, baik dalam bentuk return maupun abnormal return (Asyik, 2010). Penyataan tersebut diperkuat oleh penelitian sbelumnya oleh Courtenay dan Cahan (2004) yang menemukan bahwa revaluasi aktiva tetap bepengaruh positif terhadap return saham.

Penelitian ini menjadi menarik karena dilakukan setelah pemerintah mengeluarkan paket kebijakan ekonomi $\mathrm{V}$ pada tahun 2015, dimana diterbitkannya peraturan menteri keuangan No. 191/PMK.010/2015 yang memberikan potongan tarif pajak terhadap pelaksanaan revaluasi asset tetap, dimana diperkirakan banyak perusahaan termasuk sektor perbankan yang akan memanfaatkan kesempatan ini untuk melakukan revaluasi atas asset tetapnya. Revalasi asset yang dilakukan diyakini juga akan menyebabkan perusahaan beralih dari model biaya (historis) ke model revaluasi (fair value). Hal ini karena jika revaluasi dilakukan hanya untuk tujuan perpajakan tidak akan banyak manfaat yangakan diperoleh 
perusahaan, sehingga revaluasi aset akan cenderung dilakukan juga untuk tujuan akuntansiperusahaan.

Menurut Irwan (2015) Sektor perbankan sangat berpotensi untuk melakukan revaluasi asset untuk meningkatkan modalnya.Terutama asset tanah dan bangunan yang perolehannya sudah cukup lama dan tidak pernah direvaluasi sedangkan jika berpatokan ke NJOP nilainya naik terus setiap tahun. Peningkatan rasio kecukupan modal akan meningkatkan kapasitas bank untuk melakukan ekspansi kredit srhingga akan berpengaruh pada peningkatkan labanya.

Menurut (Asyik, 2010) dalam (Andison, 2015) revaluasi aktiva tetap dapat memberikan gambaran atau tanda yang positif bagi pihak eksternal perusahaan, karena hal ini dapat memotivasi peningkatan kinerja perusahaan yang tercemin pada laba maupun harga saham perusahaan.Kenaikan harga saham bisa menjadi satu indikator yang mengindikasikan kenaikan terhadap nilai perusahaan.Sebagai mana disebutkan bahwa nilai perusahaan merupakan persepsi investor terhadap tingkat keberhasilan perusahaan yang sering dikaitkan dengan harga saham. Menurut Untung wahyudi et.al, (2006), nilai perusahaan akan tercermin dari harga sahamnya. Sedangkan menurut (Alfaz, 2012) bahwa nilai perusahaan go public selain menunjukkan nilai seluruh aktiva, juga tercermin dari nilai pasar atau harga sahamnya, sehingga semakin tinggi harga saham mencerminkan tingginya nilaiperusahaan.

Penelitian ini cukup menarik mengingat belum ada penelitian sejenis yang khusus di lakukan pada sektor perbankan.Diduga terdapat perbedaan faktor-faktor yang menjadi pertimbangan untuk memilih model revaluasi pada sektor perbankan dibanding pada sektor manufaktur. Likuiditas merupakan salah satu hal yang menjadi pertimbangan, dimana Bank yang memiliki likuiditas yang tinggi akan lebih leluasa dalam mengambil keputusan untuk memilih metode revaluasi asset tetap mengingat besanya biaya yang harus dikeluarkan untuk revaluasi asset tetap ini. Leverage juga diduga merupakan faktor yang dipertimbangkan dalam memilih model revaluasi ini mengingat transaksi revaluasi asset ini akan meningkatkan rasio perbandingan modal terhadap hutang. Untuk perbankan revaluasi asset akan berdampak positif pada rasio kecukupan modal $(C A R)$ sehingga diduga bahwa Bank dengan rasio $C A R$ yang rendah akan cenderung untuk memilih menggunakan model revaluasi ini. Ukuran perusahaan dalam penelitian ini diproksikan dengan Log Total Aset, diyakini akan menjadi faktor yang mempengaruhi dalm pemilihan model revaluasi asset ini. Perusahaan dengan modal kepemilikan asing dianggap memberikan pengungkapan yanglebih dibandingkan dengan yangtidak memiliki kepemilikan saham asing, dikarenakan antara lain adanya 
permintaan atau tuntutan yang lebih besar dari pelanggan, pemasok dan masyarakat (Susanto, 1992) dalam (Angling 2010). Dari pembahasan sebelumnya dapat disimpulkan latar belakang masalah adalah bebagai berikut :

a) Apakah LDR perpengaruh signifikan terhadap pemilihan model revaluasi aset tetap pada sektor Perbankan?

b) Apakah $C A R$ perpengaruh signifikan terhadap pemilihan model revaluasi aset tetap pada sektor Perbankan?

c) Apakah Ukuran Perusahaan perpengaruh signifikan terhadap pemilihan model revaluasi aset tetap pada sektor Perbankan?

d) Apakah Kepemilikan Asing perpengaruh signifikan terhadap pemilihan model revaluasi aset tetap pada sektor Perbankan?

e) Apakah Likuiditas, $C A R$, Ukuran Perusahaan, dan Kepemilikan Asing perpengaruh signifikan secara simultan terhadap pemilihan model revaluasi aset tetap pada sektor Perbankan?

f) Apakah terdapat perbedaan signifikan antara pemilihan model revaluasi (fair value) dan pemilihan model biaya (historical cost) terhadap nilai perusahaan pada sector Perbankan?

\section{Signaling Theory}

Signaling Theorymengemukakan tentang bagaimana seharusnya sebuah perusahaan memberikan sinyal kepada para pengguna laporan keuangan.Teori ini menekankan pada pentingnya informasi yang dikeluarkan oleh perusahaan terhadap pihak di luar perusahaan.Informasi yang lengkap, relevan, dan akurat sangat diperlukan oleh investor dipasar modal sebagai alat analisis dalam mengambil keputusan investasi.Menurut. Informasi yang dipublikasikan akan memberikan signal bagi investor dalam pengambilan keputusan investasi. Menurut Sinaga (2014), setelah informasi diumumkan dan para pelaku pasar sudah menerima informasi tersebut maka pelaku pasar akan menginterpretasikan dan menganalisis informasi tersebut apakah sebagai signal baik (good news) atau signal buruk (badnews).

\section{Revaluasi Asettetap.}

Menurut PSAK 16 revisi 2011 : 16.6 dinyatakan bahwa suatu aset tetap yang memenuhi kualifikasi untuk diakui sebagai aset pada awalnya harus diukur sebesar biaya perolehan. Yang dimaksud dengan biaya perolehan adalah meliputi harga perolehan, bea impor dan pajak yang tidak bisa dikreditkan setelah dikurangi diskon dan potongan- potongan lainnya, serta seluruh biaya-biaya yang dapat diatribusikan secara langsung untuk membawa aset ke lokasi dan kondisi yang diinginkan agar aset siap digunakan sesuai dengan intensi 
manajemen. Setelah pengakuan awal, diberikan pilihan untuk menentukan apakah akan diukur dengan menggunakan model revaluasi atau menggunakan model biaya sebagai kebijakan akuntansinya.

Revaluasi Aset adalah penilaian kembali aset yang dimiliki suatu entitas sehingga mencerminkan nilai aset sekarang (Martani , 2010). Dengan menggunakan model revaluasi, aset tetap dicatat dengan nilai wajarnya pada tanggal revaluasi, dikurangi akumulasi penyusutan dan rugi penurunan nilai setelah revaluasi. Pengertian nilai wajar menurut PSAK 16 revisi 2011 adalah jumlah yang dipakai untuk mempertukarkan suatu aset antara pihakpihak yang berkeinginan dan memiliki pengetahuan yang memadai dalam suatu transaksi dengan wajar Apabila perusahaan menggunakan model biaya berarti aset tetap dicatat sebesar nilai perolehannya dikurangi akumulasi penyusutan dan akumulasi rugi penurunan nilai aset. Dengan menggunakan model ini, perusahaan harus melakukan uji penurunan nilai pada aset tetap dalam hal terdapat indikasi penurunan nilai.

Perusahaan harus melakukan revaluasi secara reguler terhadap satu atau lebih kelompok aset untuk memastikan jumlah tercatat tidak berbeda secara material dengan jumlah yang ditentukan menggunakan nilai wajar pada akhir pelaporan.Aset-aset dalam suatu kelompok aset tetap harus direvaluasi secara bersamaan untuk menghindari revaluasi aset secara selektif dan bercampurnya biaya perolehan dan nilai lainnya pada saat yang berbeda-beda.Apabila saat dilakukan revaluasi diketahui terjadi penurunan terhadap nilai aset tetap, maka kerugian penurunan aset tersebut dicatat melalui laporan rugi laba.Namun jika pada saat dilakukan revaluasi diketahui bahwa terjadi peningkatan terhadap nilai aset tetap, maka selisih kenaikan nilai aset tersebut harus dicatat sebagai pendapatan komprehensiflainnya.

\section{Nilai Perusahaan}

Pada dasarnya salah satu tujuan utama perusahaan adalah untuk memaksimalkan nilai perusahaan.Nilai perusahaan adalah persepsi investor terhadap tingkat keberhailan perusahaan yang terkait erat dengan harga sahamnya, dimana harga saham yang tinggi mengindikasikan nilai perusahaan yang tinggi (Sujoko dan Subiantoro, 2007). Menurut Nurlela dan Islah uddin (2008) menjelaskan bahwa nilai perusahaan merupakan konsep penting bagi investor, karena merupakan indikator bagi pasar menilai perusahaan secara keseluruhan.Sedangkan Wahyudi (2006) menyebutkan bahwa nilai perusahaan merupakan harga yang bersedia dibayar oleh calon pembeli andai perusahaan tersebut dijual. Dalam mengukur nilia perusahaan ini sudah banyak teknik atau metode yang dikembangkan antara lain dengan menggunakan price earning ratio, price to book value, dan bisa juga dengan menggunakan Tobin's Q.Dalam 
penelitian ini pengukuran nilai perusahaan dilakukan dengan menggunakan pendekatan harga saham dan kemampuan laba perusahan yaitu dengan menggunakan price earning ratio (PER). Menurut Tandelin (2007) price to earning ratio merupakan perbandingan antara harga saham dengan laba per-saham. Jadi semakin tinggi PER makakemampu labaan perusahaan juga semakin tinggi sehingga akan meningkatkan nilai perusahaan.

\section{Hubungan Likuiditas $(L D R)$ dengan Pemilihan Model Revalausi AsetTetap}

Tay (2009) melakukan penelitian di Selandia Baru menemukan bahwa perusahaan dengan likuiditas yang rendah cenderung memilih menggunakan metode revaluasi.Barac dan Sodan, (2011) di Croasia menemukan bahwa perusahaan dengan rasio likuiditas yang rendah dan rasio cashflow yang rendah cenderung untuk melakukan revaluasi asset.Firmansah (2010) melakukan penelitian di Indonesia menemukan bahwa penurunan cashflow aktivitas operasi memiliki hubungan posistif dan signifikan terhadap keputusan perusahaan untuk memilih model revaluasi aset. Hal tersebut terjadi karena perusahaan ingin meningkatkan kapasitasnya untuk mendapatkan pinjaman dengan peningkatan nilai asset yang akan digunakan sebagai jaminan hutang. Tingkat likuiditas tidak berpengaruh secara signifikan terhadap keputusan perusahaan untuk memilih model revaluasi (Putra, 2013).Menurut Nurjanah (2013) Penurunan arus kas dari aktivitas operasi tidak berpengaruh siknifikan terhadap keputusan revaluasi aktiva tetap karena aruskas operasi hanya sebagian dari arus kas perusahaan.Rasio likuiditas yang lazim digunakan dalam dunia perbankan yaitu Loan to Deposit Ratio (LDR) (Sebayang 2011). Dalam penelitian ini likuiditas akan dihitung dengan mengunakan Loan to Deposit Rasio. Dalam dunia Perbankan likuiditas diduga salah satu hal yang menjadi pertimbangan, terlepas dari hasil penelitian diatas dapat juga dipahami jika Bank yang memiliki likuiditas yang tinggi akan lebih leluasa dalam mengambil keputusan untuk memilih metode revaluasi asset tetap karena tidak terkendala dengan adanya pengeluaran biaya terkait revaluasi asset. Loan to Deposit Ratio (LDR) mempunyai pengaruh yang signifikan terhadap Profitabilitas Bank (Suwhandani dan Anggi, 2008)

H1 : Likuiditas perpengaruh negatif terhadap pemilihan model revaluasi asset tetap.

\section{Hubungan CAR dengan Pemilihan Model Revalausi AsetTetap}

Rasio kecukupan modal yang sering disebut dengan Capital Adequacy Ratio (CAR) mencerminkan kemampuan bank untuk menutup risiko kerugian dari aktivitas yang dilakukannya dan kemampuan bank dalam mendanai kegiatan operasionalnya (Idroes, 2008:69). Besaran CAR diukur berdasarkan rasio antara modal sendiri terhadap aktiva tertimbang menurut resiko (ATMR). Jumlah modal yang bank harus cadangkan untuk menutupi kerugiaan potensial yang berhubungan dengan eksposur didapat dari jumlah 
ekposur yang berisiko dengan mengkalikan bobot risiko aset dengan persyaratan modal minimum ( Direktorat Penelitian dan pengaturan Perbankan - Bank Indonesia 2006). Menurut Hutagalung, dkk (2013) CAR adalah rasio keuangan yang berkaitan dengan permodalan perbankan di mana besarnya modal suatu bank akan berpengaruh pada mampu atau tidaknya suatu bank secara efisien menjalankan kegiatannya. (Pasaribu 2011; Defri 2012; Agustiningrum 2013; Alfiah 2013) menemukan bahwa CAR berpengaruh positif terhadap Profitabilitas Bank.Namun secara teori dapat diduga bahwa Bank dengan rasio CAR yang rendah akan cenderung untuk memilih model revaluasi asset untuk meningkatkan CAR sehingga Bank lebih leluasa untuk meningkatkan ekspansi kreditnya dalam upaya peningkatan profit.

$\mathrm{H} 2$ : CAR perpengaruh negatif terhadap pemilihan model revaluasi aset tetap.

\section{Hubungan Ukuran Perusahaan (Size) dengan Pemilihan Model RevalausiAset Tetap.}

Teori akuntansi positif menyatakan bahwa perusahaan dengan ukuran lebih besar cenderung memiliki tekanan lebih besar sehingga dapat melakukan revaluasi untuk menurunkan pajak. Lin dan Peasnell (2000) dalam Manihuruk (2015) meneliti perusahaan di Inggris, mengemukakan bahwa perusahaan yang lebih besar akan melakukan revaluasi untuk mengurangi visibilitas politik dan biaya politik yang mungkin muncul. (Tay 2009; Seng dan Su 2010) melakukan penelitian di Selandia Baru menemukan bahwa perusahaan besar cenderung untuk merevaluasi aset tetap. Sedangkan penelitian di Indonesia tidak berhasil menemukan bahwa ukuran perusahaan mempengaruhi keputusan perusahaan untuk merevaluasi aset tetap (Yulistia, dkk. 2012; Nurjanah, 2013; Putra 2014), Namun Khairati (2015) dapat menemukan pengaruh ukuran perusahaan terhadap pilihan revaluasi aset pada perusahaan non manufaktur di Indonesia.

H3 : Size perpengaruh positif terhadap pemilihan model revaluasi aset tetap.

\section{Hubungan kepemilikan Asing dengan Pemilihan Model Revalausi AsetTetap.}

Kepemilikan asing adalah presentase kepemilikan saham perusahaan oleh investor asing.Menurut Undang - undang No. 25 Tahun 2007 pada pasal 1 angka 6 kepemilikan asing adalah perseorangan warga negara asing, badan usaha asing, dan pemerintah asing yang melakukan penanaman modal di wilayah Republik Indonesia (Ramadhan 2010). Perusahaan yang memiliki kepemilikan asing dianggap memberikan pengungkapan yang lebih dibandingkan dengan yang tidak memiliki kepemilikan saham asing, dikarenakan antara lain adanya permintaan atau tuntutan yang lebih besar dari pelanggan, pemasok dan masyarakat (Susanto, 1992 dalam Angling 2010). Chua et al. (2012) menemukan bahwa terdapat 
pengaruh signifikan antara kepemilikan asing terhadap perbaikan kualitas akuntansi.Menurut Hardiani (2014) penggunaan model revaluasi asset (nilai wajar) sebagai basis penilaian dalam pelaporan keuangan diyakini dapat meningkatkan relevansi pelaporan keuangan.

H4 : Kepemiikan asing berpengaruh positif terhadap pemilihan model revaluasi aset tetap.

\section{Hubungan Likuiditas, CAR, Ukuran Perusahaan (Size), dan KepemilikanAsing terhadap Pemilihan Model Revaluasi AsetTetap.}

Lin Y.C. dan Peasnell K.V. ( 2000) dalam Diana (2013) mengatakan bahwa keputusan revaluasi asset tetap dapat dipengaruhi oleh faktor-faktor ekonomi seperti likuiditas, prospek pertumbuhan, keberadaan aset yang dapat dinilai kembali, dan pola revaluasi sebelumnya. enurut Manihuruk (2015), Perusahaan yang lebih besar semakin kecil kemungkinan untuk memilih model revaluasi sedangkan intensitas asset tetap, rasio leverage dan likuiditas yang tinggi akan semakin besar kemungkinan untuk menggunakan model revaluasi. (Seng dan $\mathrm{Su}$, 2010 dalam Yustia, 2015) membagi faktor-faktor yang mempengaruhi revaluasi aset kedalam faktor pengkontarakan (contracting factor), Faktor politis (political factor) dan asimetri informasi.Revaluasi aset bisa digunakan sebagai alat untuk mengurangi rasio leverage untuk menghindari biaya kegagalan utang (debt hypothesis) serta bisa digunakan untuk memberi sinyal adanya pertumbuhan perusahaan (Azouzi dan Jarboui, 2012). Dari penelitian-penelitian yang telah disebutkan sebelumnya dapat disimpulkan hipotetis sebagai berikut:

H5 : Likuiditas, CAR, Ukuran Perusahaan (Size), dan Kepemilikan Asing secara simultan berpengaruh positif terhadap pemilihan model revaluasi aset tetap.

\section{Hubungan Pemilihan Model Revaluasi Aset Tetap dengan Nilai perusahaan.}

Pengukuran asset tetap dengan menggunakan model revaluasi (fairvalue)dianggap lebih relevan karena lebih mencerminkan nilai yang sebenarnya dibanding menggunakan pengukuran dengan model biaya (historical cost). Menurut Puspatiningtyas (2012), relevansi nilai lebih menekankan pada bagaimana informasi akuntansi relevan bagi para investor dalam menjelaskan nilai perusahaan di pasar modal. Dengan kata lainsebuah informasi dikatakan relevan jika informasi tersebut dapat dipakai sebagai dasar bagi pengambilan keputusan bisnis, relevansi nilai informasi akuntansi sangat penting karena dapat digunakan sebagai dasar dalam pengukuran nilai perusahaan di pasar modal. (Barth, et al., 2001, dalam Sinaga 2014). Kebijakan revaluasi juga memberikan sinyal bahwa investor memiliki peluang untuk memperoleh keuntungan atas investasinya, baik dalam bentuk return maupun abnormal return . Penyataan tersebut diperkuat dengan penelian Courtenay dan Cahan (2004) membuktikan bahwa revaluasi aktiva tetap bepengaruh positif terhadap returnsaham.

H6 :Pemilihan model revaluasi aset tetap berpengaruh positif terhadap nilai perusahaan. 


\section{METODOLOGI}

Model penelitian yang digunakan dalam penelitian ini adalah sebagai berikut :.

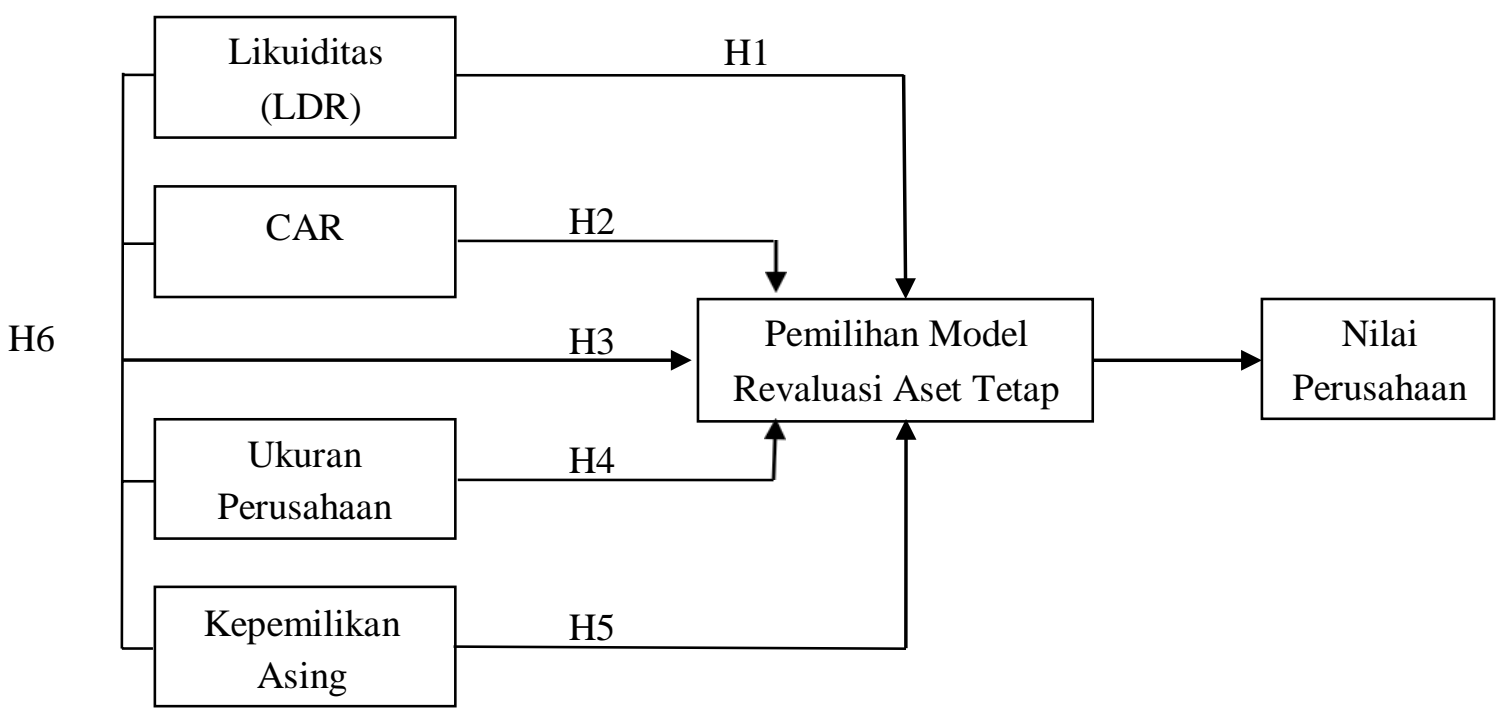

Gambar 1. Model Penelitian

\section{Variabel Dependen}

Variabel dependen dalam penelitian ini adalah pemilihan model revaluasi. penelitian ini sesuai dengan peneliti-peneliti sebelumnya yang juga menguji pemilihan model revaluasi (Seng dan Su, 2010; Piera, 2008) Pengukuran variabel ini sama dengan pengukuran yang digunakan oleh Seng dan Su (2010) yaitu nilai 1 untuk perusahaan yang memilih model revaluasi dan nilai 0 untuk perusahaan yang memilih model biaya.

\section{Variabel Independen}

Variabel independen pada tahap pertama penelitian ini ada 4 yaitu likuiditas, CAR, ukuran perusahaan dan kepemilikan pemerintah.

\section{a. Loan to Deosit Ratio $(L D R)$}

Karena penelitian ini dikhususkan pada sektor Perbankan maka likuiditas dalam penelitian ini diproxikan dengan Loan to Deposit Ratio atau (LDR). Adapun pengeritan Loan to Deosit Ratio (LDR) adalah rasio yang mengukur likuiditas bank dalam memenuhi dana yang ditarik oleh masyarakat dalam bentuk tabungan dan deposito Kasmir (2012:319). Rumus perhitungannya adalah : 


$$
\mathrm{LDR}=\frac{\text { Total Kredit }}{\text { Total Dana Pihak Ketiga }} \quad \mathrm{X} 100 \%
$$

\section{b. Capital adequacy ratio $(C A R)$}

Capital adequacy ratio (CAR) adalah rasio kinerja bank untuk mengukur kecukupan modal yang dimiliki bank untuk menunjang aktiva yang mengandung atau menghasilkan risiko yang dibiayai dari dana modal sendiri atau sumber dana yang berasal dari luar bank Astrini (2014). Rasio CAR dapat dihitung dengan rumus :

\section{Modal Bank}

$\begin{array}{cl}\text { CAR }= & \\ \text { Aktiva Tertimbang Menurut } & \text { X } 100 \% \\ \text { Resiko } & \\ \text { CAR }=\text { kuran Perusahaan }(\text { Size }) & \end{array}$

Ukuran perusahaan dalam penelitian ini diukur dengan menggunakan natural logaritma dari total asset sebelum penyesuaian revaluasi (Seng dan $\mathrm{Su}, 2010$ ).

c. Kepemilikan Asing

Menurut Undang - undang No. 25 Tahun 2007 pada pasal 1 angka 8 kepemilikan modal asing adalah modal yang dimiliki oleh Negara asing, perseorangan warga negara asing, badan usaha asing, badan hukum asing, dan/atau badan hukum Indonesia yang sebagian atau seluruh modalnya dimiliki oleh pihak asing.

\section{Variabel Penelitian Tahapke-dua}

Pada tahap ke-dua penelitian ini terdiri dari dua variable yaitu :

a. Nilai perusahaan

Nilai perusahaan merupakan harga yang bersedia dibayar oleh calon pembeli apabila perusahaan tersebut dijual (Suad, 2008:7). Menurut Keown, et al. (2007) nilai perusahaan adalah nilai pasar atas surat berharga hutang dan ekuitas perusahaan yang beredar. Untuk menghitung nilai perusahaan banyak metode atau pendekatan yang sudah kembangkan, namun dalam penelitian ini penulis menggunakan Price Earnings Ratio (PER) yaitu perbandingan antara harga saham dengan laba per saham, atau dapat digambarkan dengan rumus sebagai berikut:

$$
\text { PER }=\frac{\text { Harga Per Lembar Saham }}{\text { Laba Perlembar Saham }}
$$

b. Pemilihan model revaluasi asset tetap 
Dalam penelitian ini perbankan yang pengukuran asset tetapnya setelah pengakuan awal memilih model revaluasi asset tetap (fair value) akan di berikan nilai 1, sedangkan perbankan yang memilih pengukuran asset tetapnya dengan model biaya (historical cost) di berikan nilai 0 .

\section{Metode dan DesainPenelitian}

Metodologi yang digunakan dalam penelitian ini adalah metode kuantitatif dengan mengkaji pengaruh Likuiditas, CAR, Ukuran Perusahaan (Size) dan Kepemilikan Asing terhadap pemilhan model revaluasi asset tetap pada sektor Perbankan. Dari hasil penelitian ini didaptkan pembuktian hipotesis yang dibangun dari teori dan analisis hubungan Likuiditas, CAR, Ukuran Perusahaan (Size), dan Kepemilikan Asing terhadap pemilihan model revaluasi asset tetap.Dan pembuktian apakah ada pengaruh pemilihan model revaluasi asset tetap terhadap nilai perusahaan.

\section{Sumber Data dan Sampel Penelitian}

Penelitian ini menggunakan data sekunder yang diperoleh dari pusat data Bursa Efek Indonesia di www.idx.co.id.Sampel dipilih dari populasi perusahaan sektor Perbankan yang terdaftar di BEI (Bursa Efek Indonesia) pada tahun 2015 - 2016. Menurut Jemmy Rumengan (2013 : 51) sampel adalah bagian dari populasi dengan karakteristik yang dianggap mewakili populasi penelitian. Adapun sampel dalam penelitian ini adalah berdasakan purposive sampling, dengan kriteria yang ditetapkan sebagai berikut :

a. Perusahaan sektor Perbankan yang terdaftar di Bursa Efek Indonesia periode tahun (2015-2016).

b. Perusahaan sektor Perbankan yang menerbitkan laporan keuangan yang lengkap periode tahun (2015 - 2016) yang telah diaudt.

c. Memiliki kelengkapan data yang dibutuhkan selama priodepengamatan.

d. Perusahaan yang laporan keuangannya tidak mengalami kerugian.

\section{PEMBAHASAN DAN ANALISIS}

\section{Regresi Logistik}

Penelitian ini menganalisis data dengan menggunakan regresi logistik karena dependen variabel yang merupakan variabel dichotomous, dalam hal ini adalah untuk menguji pilihan apakah memilih model revaluasi asset atau memilih model biaya. Pengujian logistik ini tidak menggunakan uji normalitas dan uji asumsi klasik pada variabel bebasnya (Ghozali, 2011; Karim 2013). Model regresi logistik yang digunakan dalam penelitian ini adalah 
sebagai berikut :

P.REVi $=\alpha+\beta 1 \mathrm{LDRi}+\beta 2 \mathrm{CARi}+\beta 3 \mathrm{SIZEi}+\beta 4 \mathrm{KAi}+\mathrm{ei}$

Keterangan :

P.REVi = Probabilita jika perusahaan memilih model revaluasi nilai $=1$, dan jika memilih menggunakan model biaya nilai $=0$.

$\alpha \quad=$ Konstanta.

$\beta 1-\beta 4=$ Koefisienregresi. LDRi =Likuditas

CARi $=$ Rasio Kecukupan Modal

SIZEi $=$ Ukuran perusahaan $($ Size $)$

$\mathrm{KAi}=$ KepemilikanAsing

$\mathrm{Ej} \quad=$ error

\section{UjiMann-Whitney}

Untuk menguji hippotesis H6, apakah ada pengaruh positif pemilihan model revaluasi asset tetap terhadap nilai perusahaan pada sektor perbankan digunakan uji Mann-Whitney, dan derajat signifikansi yang digunakan adalah $\alpha=0,1$. Uji ini merupakan alternative bagi uji $\mathrm{t}$, yang digunakan untuk membandingkan dua mean poulasi yang bersal dari populasi yang sama. Dari uji ini akan diketahuai apakah pemilihan model revaluasi asset (fair value) lebih berdampak pada peningkatan nilai perusahaan jika dibandingkan dengan memilih model biaya (historicalcost).

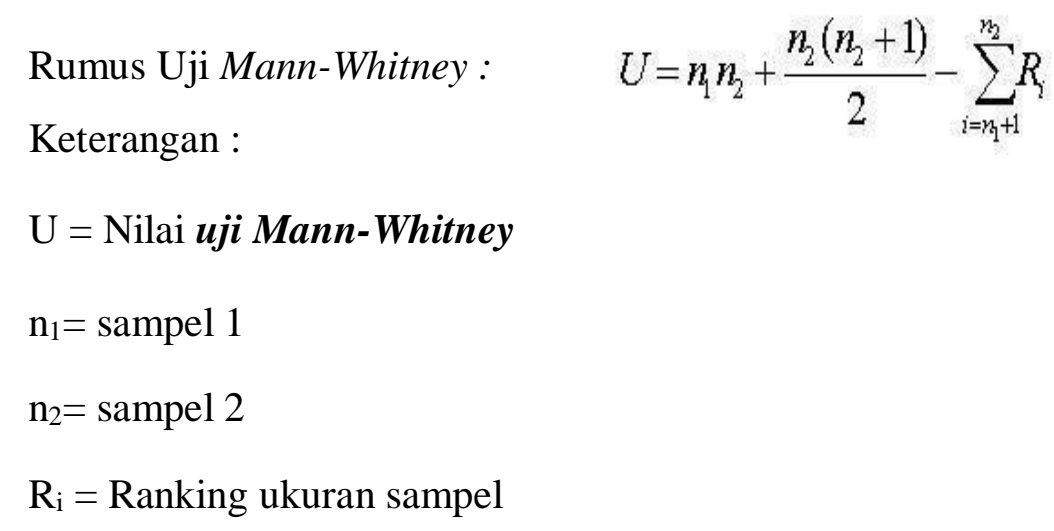

\section{Sampel dan Statistik Deskriptif}

Adapun jumlah perusahaan yang menjadi populasi dalam penelitian ini adalah seluruh perusahaan perbankan yang terdaftar di BEI periode tahun 2015-2016 yang berjumlah 37 Bank.Berdasarkan kriteria yang ditetapkan didapatkan sampel penelitian berjumlah28 Bank. Dari jumlah sampel tersebutdiketahui perbandingan jumlah Bank yang memilih model revaluasi dan perusahaan yang memilih model biayasebagai berikut: 
Tabel 1. Klasifikasi Perusahaan yang Memilih Model Revaluasi dan yang Memilih Model Biaya.

\begin{tabular}{cccc}
\hline Tahun & Model Revaluasi & Model Biaya & Total \\
\hline 2015 & 13 & 15 & 28 \\
2016 & 20 & 8 & 28 \\
\hline Total & 33 & 23 & 56 \\
\hline
\end{tabular}

Berikut ini adalah tabel statistikdeskriptif yang menampilkan tentang jumlah sampel, nilai minimum tiap varibel, nilai maksimum tiap variable, nilai rata-rata serta standar deviasi masing-masing variabel

Table 2. Statistik Deskriptif

\begin{tabular}{|c|c|c|c|c|c|}
\hline \multicolumn{6}{|c|}{ Descriptive Statistics } \\
\hline & $\mathrm{N}$ & Minimum & Maximum & Mean & Std. Deviation \\
\hline LDR & 50 & 55.35 & 113.00 & 88.8489 & 12.35329 \\
\hline CAR & $5 \notin$ & 14.37 & 89.86 & 21.5436 & 10.10806 \\
\hline SIZE & $5 \notin$ & 9.85 & 15.02 & 13.4532 & 1.00775 \\
\hline FOW & 56 & .00 & 96.90 & 33.998 & 33.36743 \\
\hline Valid N (listwise) & $5 \phi$ & & & & \\
\hline
\end{tabular}

\section{Analisis Regresi Logistik}

Peneliti menggunakan regresi logistik untuk menguji Likuiditas, CAR, Ukuran Perusahaan, dan Kepemilikan Asing apakah berpengaruh signifikan terhadap kepututusan pemilihan model revaluasi asset tetap.

a) Menilai Kelayakan Model Regresi (Goodness of FitTest)

Untuk menguji kelayakan model regresi dapat dilihat dari nilai chi-square pada tabelberikut ini :

Tabel 3. Hasil Uji Kelayakan Model Regresi

(Goodness of Fit Test)

Hosmer and Lemeshow Test

\begin{tabular}{|l|r|r|r|}
\hline Step & Chi-square & df & \multicolumn{1}{|c|}{ Sig. } \\
\hline 1 & $4.30 \mathrm{~g}$ & & -744 \\
\hline
\end{tabular}


Nilai chi-square sebesar 4,309 dengan probabilitas signifikansi lebih besar dari 0.05 yaitu sebesar 0,744maka secara statistik dapat disimpulkan bahwa model mampu memprediksi nilai observasinya dan model dapat diterima karena cocok dengan data observasinya.

\section{b) Nagelkerke $R$ Square}

Untuk mengetahui kemampuan variabel independen dalam menjelaskanvariabel dependen dengan melihat nilai Nagelkerke $R$ Square yang disajikan pada tabel berikut:

Tabel 4. Hasil Uji Nagelkerke R Square.

\begin{tabular}{|l|r|r|l|}
\hline \multicolumn{4}{|c|}{ Model Summary } \\
\hline Step & -2 Log likelihood & $\begin{array}{c}\text { Cox \& Snell R } \\
\text { Square }\end{array}$ & $\begin{array}{c}\text { Nagelkerke R } \\
\text { Square }\end{array}$ \\
\hline 1 & 60.191 & .244 & .329 \\
\hline
\end{tabular}

a. Estimation terminated at iteration number 6 because parameter estimates changed by less than .001 .

Dari tabel 4 dapat dilihat bahwa nilai Nagelkerke $R$ Square adalah 0.329 hal ini menunjukkan bahwa variable independen mampu menjelaskan sebesar 32,9\% terhadap variable bebas, sedangkan sisanya sebesar $67,1 \%$ dijelaskan oleh faktor lain diluar variable independen yang ada dalam peneitian ini.

c) Uji Parsial

Pengujian hipotesis untuk menguji bagaimana pengaruh masing-masing variabel independen terhadap variable dependen dapat dilihat pada tabel berikut:

Tabel 5. Hasil Uji Hipotesis

Variables in the Equation

\begin{tabular}{|c|c|c|c|c|c|c|c|}
\hline & & B & S.E. & Wald & $d f$ & Sig. & $\operatorname{Exp}(B)$ \\
\hline \multirow[t]{5}{*}{ Step $1^{a}$} & LDR & $-.01 \oint$ & .028 & .403 & 1 & .525 & .982 \\
\hline & CAR & .113 & .096 & 1.390 & 1 & $.23 \oint$ & $1.11 \mathrm{~g}$ \\
\hline & SIZE & 1.533 & .573 & 7.153 & 1 & .007 & 4.634 \\
\hline & FOW & -.004 & .013 & .100 & 1 & .745 & .996 \\
\hline & Constant & $-20.92 d$ & $8.62 €$ & 5.882 & 1 & .015 & .000 \\
\hline
\end{tabular}

a. Variable(s) entered on step 1: LDR, CAR, SIZE, FOW.

Dari tabel 5 diatas dapat dilihat bahwa hanya Size (ukuran perusahaan) yang berpengaruh signifikan terhadap pemilihan model revaluasi asset tetap.Sedangkan variable 
LDR (Loan to Deposite Ratio), CAR(Capital Adequacy Ratio) dan FOW(Foreign Ownership) tidak berpengaruh secara signifikan terhadap pemilihan model revaluasi asset.

d) Uji Simultan

Untuk mengetahui pengaruh $L D R, C A R$, SIZE dan Kepemilikan Asing secara simultan terhadap pemilihan model revaluasi asset dapat dilihat dari tabel 5.6 dimana nilai signifikansi omnibus test $0.004<0,05$ ini menunjukkan bahwa dengan tingkat kepercayaan $95 \%$ variable independen ( $L D R, C A R$, SIZE dan Kepemilikan Asing) berpengaruh signifikan secara simultan terhadap pemilihan model revaluasi asset.

Tabel 6. Uji Simultan

Omnibus Tests of Model Coefficients

\begin{tabular}{|rr|r|r|r|}
\hline & & Chi-square & df & \multicolumn{1}{c|}{ Sig. } \\
\hline Step 1 & Step & 15.649 & 4 & .004 \\
& Block & 15.649 & & .004 \\
& Model & $15.64 €$ & & .004 \\
\hline
\end{tabular}

\section{Uji Mann-Whitney}

Untuk menguji apakah ada pengaruh pemilihan model revaluasi asset tetap terhadap nilai perusahaan maka digunakan uji Mann-Whitney mengingat data yang di uji adalah data ordinal sertatidak terdistribusi normal.

Tabel 7. Uji Mann-Whitney

\begin{tabular}{|ll|r|r|r|}
\hline \multicolumn{2}{|c|}{ Ranks } & \\
\hline Nilai Perusahaan & Revaluasi Aset & $\mathrm{N}$ & Mean Rank & Sum of Ranks \\
& Tidak & 23 & 31.17 & 717.00 \\
& Ya & 33 & 26.64 & 879.00 \\
& Total & 56 & & \\
\hline
\end{tabular}

Test Statistics ${ }^{a}$

\begin{tabular}{|l|r|}
\hline & Nilai Perusahaan \\
\hline Mann-Whitney U & 318.00 \\
Wilcoxon W & 879.00 \\
Z & -1.02 \\
Asymp. Sig. (2-tailed) & .306 \\
\hline
\end{tabular}

a. Grouping Variable: Revaluasi Aset

Dari hasil output SPSS dapat dilihat bahwa nilai Asymp. Sig. (2-tailed) 0.306 lebih besar dari 0.05 sehingga dapat disimpulkan bahwa tidak ada perbedaan antara yang menggunakan model revaluasi asset tetap dan menggunakan model biaya terhadap nilai 
perusahaan.Sehingga dapat disimpulkan bahwa tidak ada pengaruh signifikan pemilihan model revaluasi asset tetap terhadap nilai perushaan.

\section{KESIMPULAN DAN SARAN}

\section{Kesimpulan}

Berdasarkan hasil uji analisis dan pembahasan yang telah dilakukan dalam penelitian ini maka dapat disimpulkan sebagai berikut :

a) $L D R$ berpengaruhnegatif dan tidak signifikan terhadap pemilhan model revaluasi asset tetap.Meskipun pengaruhnya tidak signifikan hal ini sejalan dengan hipotesis penelitian, dan dapat dijelaskan dimana Bank dengan likuiditas $(L D R)$ yang kecil akan memilih untuk menggunakan model revaluasi asset untuk meningkatkan nilai asetnya sebagai upaya untuk meningkatkan kemampuannya dalam memperoleh pinjaman karena nilai agunan yang meningkat.

b) CAR berpengaruh posistif dan tidak signifikan terhadap pemilhan model revaluasi asset tetap. Hal ini tidak sejalan dengan hipotesis penelitian namuan diduga pengaruh positif ini terjadi dengan penjelasan bahwa Bank dengan rasio CAR yang lebih tinggi memiliki keleluasaan dan kemampuandana yang lebih untuk melakukan revaluasi asset tetap mengingat biaya-biaya yang akan timbul atas pelaksanaan revaluasi asset.

c) SIZE berpengaruh positif dan signifikan terhadap pemilhan model revaluasi asset tetap. Hal ini sesuai dengan hipotesis penelitian, dimana perusahaan yang lebih besar cenderung untuk mendapat tekanan yang lebih sehingga akan melakukan revaluasi untuk mengurangi visibilitas politik dan biaya politik yang mungkin muncul.

d) Kepemilikan Asing berpengaruh negatif dantidak signifikan terhadap pemilihan model revaluasi asset tetap. Meskipun tidak berpengaruh signifikan hasil ini tidak sejalan dengan hipotesis penelitian, pengaruh negatif kepemilikan asing terhadap pemilihan model revaluasi asset ini di duga terjadi karena Bank asing tersebut tidak tetarik untuk melakukan revaluasi asset untuk menghindari pembayaran pajak yang lebih besar, meskipun pada periode penelitian terdapat paket kebijakan pemerintah yang memberikan insentif berupa penurunan tarif pajak untuk pelaksanaan revaluasi asset tetap.

e) Secara Simultan LDR, CAR, SIZE, dan Kepemilikan Asing berpengaruhsignifikan terhadap Pemilihan Model Revaluasi Asset Tetap. Penelitian ini sesuai dengan hipotesis penelitian, jika dilihat dari nilai Nagelkerke $R$ Square maka dapat disimpulkan bahwa variable $L D R, C A R$, SIZE, dan Kepmilikan Asing mampu mempengaruhi pemilihan model revaluasi sebesar $32,9 \%$, sedangkan sebesar $67,1 \%$ dipengaruhi oleh variable lain 
yang tidak dibahas dalam penelitian ini.

f) Tidak terdapat perbedaan signifikan antara pemilihan model revaluasi (fair value) dan pemilihan model biaya (historical cost) terhadap nilai perusahaan. Hal ini diduga bahwa para investor tidak begitu terpengaruh dengan pemilihan model revaluasi asset tetap karena menganggap peningkatan nilai asset dari kegiatan revaluasi sesuatu yang wajar saja sehingga tidak mempengaruhi keputusan. Dalam hal ini diduga para investor memepelajari laporan keuangan dengan baik termasuk metode yang digunakan dalam pengukuran nilai asetnya.

\section{Keterbatasan Penelitian dan Saran}

a) Penelitian ini menggunakan sampel yang relatif sedikit, dikarenakan periode penelitian hanya 2 tahun (2015-2016).

b) Sampel yang digunakan dalam penelitian ini hanya terfokus pada sektor perbankan yang terdaftardibursa efek Indonesia, sehingga kesimpulan yang dihasilkan dari penelitian ini tidak dapat digeneralisasi pada sektor industri lainnya.

c) Sampel yang digunakan bisa diperluas yaitu dengan memperpanjang periode pengamatan.

d) Untuk penelitian selanjutnya dapat dilakukan dengan menambahkan beberapa variabel yang secara teoritis diduga memiliki pengaruh terhadap pemilihan model revaluasi asset tetap.

\section{REFERENSI}

Andison (2015) Fixed Asset Revaluation: Market Reactions Simposium Nasional Akuntansi 18 Universitas Sumatera Utara, Medan.

Azouzi and Jarboui (2012).The Evidence of Management Motivation to Revalue Property Plant and Equipment in Tunisia. African Journal of Hospitality, Tourism and Leisure Vol. 2 No. 1

Barac, Zeljana Aljinovic dan Slavko Sodan, 2011.Motives for Asset Revaluation Policy Choice in Croatia, Croation Operational Research Review (CRORR), Vol 2.

Ikatan Akuntan Indonesia, 2012. Standar Akuntansi Keuangan, Ikatan Akuntan Indonesia, Jakarta.

Khairati, Adzkya, 2015. Pengaruh Leverage, Firm Size dan Fixed Asset Intensity terhadap Keputusan Perusahaan Melakukan Revaluasi Aset Tetap, Skripsi, Universitas Bung Hatta, Padang.

Lin, Y. C. and Peasnell, K. V. (2000).Fixed asset revaluation and equity depletion in 
UK.Journal of Business Finance and Accounting, 27, 359 - 394.

Manihuruk, T dan Farahmita, A (2015).Analisis Faktor-Faktor yang empengaruhi Pemilihan Metode Revaluasi Aset Tetap pada Perusahaan yang Terdaftar di Bursa Saham Beberapa Negara ASEAN. Simposium Nasional Akuntansi 18 Universitas Sumatera Utara, Medan

Martani, Dwi, 2011. Revaluasi Aset Tetap, www.staff.blog.ui.ac.id/martani/ pendidikan / artikel-psak/ revaluasi-aset-tetap / diakses Maret 2016.

Nurjanah, Ai. 2013. Faktor-Faktor yang Berpengaruh terhadap Keputusan Revaluasi Aset Tetap pada Perusahaan yang Listing di Bursa Efek Indonesia tahun 2011, Skripsi Universitas Pendidikan Indonesia.

Piera, Frank Missioner, 2007. Motives for Fixed Asset Revaluation: An Empirical Analysis with Swiss Data, The International Journal of Accounting, 42.

Paik, Gyung. (2009). The Value Relevance of Fixed Asset Revaluation Reserves in International Accounting. International Management Review Vol. 5 No. 2. 2009.

Seng, Dyna dan Jiahua Su, 2010. Managerial Incentives Behind Fixed Asset Revaluation, International Journal of Business Research, Vol. 10, No. 2.

Tay, Ink, 2009. Fixed Asset Revaluation: Management Incentives and Market Reactions, Thesis, Lincoln University, Vew Zealand.

Wang, Zhemin, 2006. Upward Revaluation of Fixed Assets, Journal of Business and Economics Research Vol. 4, No. 1

Yulistia dkk 2015.Pengaruh Leverage, Arus Kas Operasi, Ukuran Perusahaan dan Fixed Asset Intensity Terhadap Revaluasi Aset Tetap, Simposium Nasional Akuntansi 18 Universitas Sumatera Utara, Medan. 